\title{
Samarinda City Branding through Tourism Communication of Dayak Village in Pampang
}

\author{
${ }^{1}$ Tuti Widiastuti, ${ }^{2}$ Eli J. Mihardja, ${ }^{3}$ Prima M. Agustini \\ Bakrie University, Jl. HR Rasuna Said Kav. C-22, Jakarta 12920, Indonesia. \\ E-mail: 1'tuti.widiastuti@bakrie.ac.id, ${ }^{2}$ eli.mihardja@bakrie.ac.id, ${ }^{3}$ prima.agustini@bakrie.ac.id
}

\begin{abstract}
The Dayak village in Pampang, Samarinda in East Kalimantan has cultural potential, especially the performing arts utilized to support the development of regional tourism. For this reason, this study aims to find out how Dayak cultural symbols in the village of Pampang was used for the strategy of Samarinda city branding. The symbolic interactionist perspective is used to analyze the use of cultural symbols in the imaging of a city. The research method used is descriptive qualitative. Data is collected from interviews with various informants from government, community leaders, and traditional leaders. The research findings indicated that the performing arts were used as a resource in tourism development with a cultural perspective. Cultural symbols in the performing arts can be a means of symbolic interaction of the Dayak culture in Pampang between the community and domestic and foreign tourists who come to this village. This cultural performance can be an attraction of Samarinda City, which has minimal potential for nature tourism. The utilization of regional cultural potential can be maximized through increased support from formal and informal institutions to manage this potential to support the image of the city.
\end{abstract}

Keywords: city branding, symbolic interactionism, tourism communication, Dayak village, Pampang.

\section{INTRODUCTION}

Indonesia is very rich in cultural diversity, customs, and traditions in various ethnic groups. The abundance of natural wealth and the culture and traditions that Indonesia possesses does not make Indonesia become divided. It is precise with this diversity that is one of the supporting factors for Indonesia to unite and move forward. Behind this created unity contains many aspects of the communication strategy, including the community's problems regarding the values of the old man's life which are currently used for cultural tourism potential, especially regarding the ancestral assets owned by each tribe.

Samarinda City is the capital of the province of East Kalimantan, Indonesia, and the largest city in the entire island of Kalimantan. It has now become a city that has the branding TEPIAN (Shady, Neat, Safe and Comfortable) having rural cultural tourism Pampang, which is a cultural tourism area that shows the life of the Dayak Kenyah culture itself. In this village, tourists can see first-hand the culture and customs of the Dayak people, one of the oldest tribes living in the archipelago.

The appeal of the cultural uniqueness of the Village of Pampang is that indigenous people still maintain their ancestral culture as a preserved tradition. Pampanga's culture has never been damaged by current modernization, which is always present in the village through the arrival of tourists both from 
Tuti Widiastuti, dkk. Samarinda City Branding through Tourism Communication..

home and abroad who are interested and come to visit Pampang. For example as if important events held every year always get the attention of the visitors in the village of Pampang.

This article seeks to identify, identify, and deepen understanding of the symbols contained in the culture of the Pampang Village. The author also believes that cultural objects found in the village of Pampang, both inanimate and living, can produce meaning through the communication process, both in terms of verbal and non-verbal messages and have the ultimate goal by interpreting symbols, based on mutual agreement that applies in the Pampang Village area. The Symbolic Interactionism Theory thoroughly describes how writers outside the Dayak ethnic group perceive the population of Pampang Village so that there are aspects of culture that the population tries to introduce to the outside communities of Pampang Village.

Mead examines social interactions about two or more individuals who have the potential to emit meaningful symbols (Fitraza, 2008). As is the case with culture in Pampang Village, they are more confident. The population in the village has the potential to emit meaningful symbols. through management activities carried out by villagers based on symbols given by their ancestors. Pampang residents can express their feelings, thoughts, intentions, and vice versa through reading the signs obtained from the ancestors.

Interactional perspective is one of the perspectives in communication studies that have a humanist aspect (Ardianto, 2007, p. 40), so the cultural work of the people in Pampang Village represents the grandeur of the influence of ancestral values. The traditional houses of this village are usually referred to by the locals as "Lamin." This house has an interior ornament that is unique.
In traditional tribal houses in Indonesia; the Dayak tribe has a distinctive type and form of carving, in which each symbol has a different meaning. Dayak tribes not only make carvings and ornaments on the interior and exterior of a building, but also on household furniture, traditional ritual tools, and even clothes that have different ornaments. The Lamin's ornaments are philosophical in the beliefs of the Dayak people towards their ancestors. The Dayak people apply their respect and belief through an art form that is sculpture. They carved walls, pillars, and even the wooden foundations of Lamin's house. Each of these ornaments has a particular meaning and function, both in terms of beliefs and philosophies. People use it in their work and especially in traditional rituals. Through art in particular making ornaments, they can express their identity, what they believe in, and their views of the natural surroundings, about their lives.

\section{City Branding}

Cities in developing countries do not have many specialized functions (Nallari, Griffith, \& Yusuf, 2012, pp. 55-82)(Yananda \& Salamah, 2014, p. 22 ), yet cities in developed countries have highly specialized with advanced economic stages and urbanization. Cities in developed countries were making the transition from manufacturing to service cities and specialized in a variety of service activities that present a new city typology. Among the typologies are cities of knowledge, creative cities, global cities, and green cities (Sugiarsono, 2009).

City marketing or place marketing is closely related to the construction, communication, and management of the city's image (Kavaratzis, 2004a) so that the articulation of city images is very important in marketing a city. Another case with a place brand, specifically a 
city branding. This process provides a different focus on city marketing. The process of city branding is related to the formation of city identity which is different in nature and directs how a city is marketed (Oktaviani, 2018, p. 204) . Branding is carried out to secure economic and competitive advantages, community development and cohesion, and increase civic engagement and identity with a place. When a place has shifted from a product to a brand, the city becomes an object that can confirm identity (Kavaratzis, 2004b).

Identity is an instrument that is the basis of the branding process. Identity allows a place to be different from other places that become competitors (Moilanen \& Rainisto, 2009) (Kotler, 2003). Image is a projection of identity (Keskin, Akgun, Zehir, \& Ayar, 2016). If identity compare to an object, then the image is the image of the object reflected in the mirror. The image is not an object itself, but rather a reflection of its identity. The ideal image is an image that is close to the identity of something or someone, displaying the object as a whole, complete, and not experiencing distortion.

City branding is believed to have the power to change someone's perception of a city or aim to see the difference in the potential of a city with other cities. The picture above is an explanation of the six hexagon city brand from Anholt (Pramiyanti, 2013, p. 5) that must be considered by marketers as a frame of reference for understanding, analyzing, and designing strategies in creating city branding that is suitable for its target market. City branding consists of six components as follows:

a.Presence

Presence is the stage to comprehend the excellence, the characteristics of a city. Visitors will have different perceptions of a city. Usually, they go around the city to see the uniqueness that exists.

\section{b. Place}

The place component is related to the physical aspects of a city such as location. A city must prioritize the comfort and cleanliness of its environment so that it becomes a positive value for visitors. Besides, visitors also see what is interesting from its city facilities such as buildings and parks.

c. Potential

Potential is related to economic and educational opportunities. The government can reading the situation whether the city is functioned as a business opportunity or not.

d. Pulse

The pulse component related to lifestyle that is developed from a city.

e. People

The city's attitude towards change regarding the security of its citizens is a matter of interest. It is associated with the hospitality of the city community that can make visitors happy to destine to the city. f. Prerequisites

The last component is the prerequisite; this component questions about perceptions about the quality of life of a city. It is considered a city where can stay through events, public infrastructure, accessibility, and other supporting facilities.

\section{Symbolic Interactionism}

Symbolic Interactionism is a theory used to explain the culture of the Village of Pampang and also the Dayaks. The symbolic interactionism cannot be separated from the thought of George Harbert Mead (1863-1931). According to Mead, symbolic interaction theory has basic ideas in forming a meaning derived from the human mind about self, and its relationship during social interaction, and aims at the end to meditate and interpret meaning in the middle of society where the individual's neighborhood settled. As noted by Douglas (1970) meaning comes 
Tuti Widiastuti, dkk. Samarinda City Branding through Tourism Communication..

from interaction, and there is no other way to shape meaning, other than by building relationships with other individuals through interaction (Ardianto, 2007, p. 136).

The definition of the three basic ideas of symbolic interaction includes Mind, Self, and Society. The mind is the ability of how individuals use symbols that have the same social meaning, where later, each individual must develop their thoughts through interactions with individual opponents. The self is a reflection of individual and the assessment of viewpoints or perceptions of others, and the theory of symbolic interactionism is one of the branches in the sociology theory that proposes about oneself or theself and the external world.

Society is like a network of social relationships created, built, and constructed by each individual in the middle of society. Each individual is involved in behaviors that they choose actively and voluntarily, which ultimately deliver humans in the process of taking roles in the middle of the community.

Mind, self, and society is the most famous work of George Harbert Mead (1934) which in this book has a focus on three theme concepts and assumptions needed to clear explanations about the symbolic interaction (West \& Turner, 2008, p. 96). The first theme in symbolic interaction is focused on the formation of meaning for human behavior that cannot be separated from the communication process, which is the initial sign has no meaning. The meaning is formed in the interpretive process in the process of interaction between individuals. Then the process of interaction that takes place creates meaning that will mutually agree (Dila, 2008) (Nugraha, Yustikasari, \& Koswara, 2017).

The above statement is consistent with three of the seven assumptions by Herbert Blumer (1969; West \& Turner,
2008, p. 99), as follows:

1. Human act to others is based on the meaning given by others to them.

2. Meaning is made in human interaction.

3. Modified meaning is created through an interpretive process.

Next, the second theme on symbolic interaction focuses on the importance of "self-concept" or "self-concept." Where, the theme of this symbolic interaction emphasizes the development of self-concepts through the individual actively, based on social interaction with others. This theme has two additional assumptions, according to LaRossan \& Reitzes (1993) including (West \& Turner, 2008, p. 101):

1. Individuals develop self-concepts through interactions with others.

2. Self-concepts form important motives for behavior.

Finally, the last theme of symbolic interaction is related to the relationship between the freedom of an individual and society. The assumption also says that there are social norms that apply and limits the behavior of each individual, but later at the end of the individual itself that determines choices existing in a social community. The assumptions related to this theme are people and community groups are influenced by cultural and social processes.

\section{Tourism Communication}

According to Bungin (2015, p. 94) tourism communication has several important areas of study that are developed as interesting fields of study. These fields will continue to develop in the future in line with the growing complexity of studies in tourism communication. The field of tourism communication marketing or TMC examines the whole in the context of marketing communication. This field of study explains 4P, 7P, Communication Mix, Marketing Mix, and matters concerning TMC. 
The principles of communication management become reviews conducted and applied in the field of tourism communication. This study reviews how management is applied in the field of tourism communication, namely how to manage tourism marketing, manage destinations, manage accessibility and manage human resources and tourism institutions. What is the role of leaders and leadership and how to manage people, manage budgets and manage tourism communication tools and machines (Burhan, 2015, p. 95).

\section{METHOD}

The research method used is descriptive qualitative presenting more data to words, sentences, or images, also in the form of interview scripts, field notes, video recordings, personal documents, official documents or memos, and other official documents (Moleong, 2000, p. 6).

Data collection is the process of procuring primary data for the needs of a study. Data collection is an essential step in the scientific method because, in general, the data collected used in the framework of research analysis (Sugiyono, 2013, p. 229). In collecting data use several methods or techniques as follows: interviews, observation, and documentation.

List of informants in this research as follows:

1. Head of E-Government Application and Services Division, Samarinda's Office of Communication and Information.

2. Head of Regional Infrastructure, BAPPEDA Samarinda.

3. Head of Self-Assessment for Regional Revenue Improvement in East Kalimantan.

4. Head of Development, Tourism Resources Development City of Samarinda.

5. Head of Tourism Destination and Business Development Division,
Samarinda City Tourism Office.

6. Head of Pampang Village Art.

7. Pampang villagers.

8. Pampang village dancers.

Data that is collected from government informants agencies includes regional development policies, the direction of tourism development, and the utilization of local social-cultural potential for the city's image. Information collected from community leaders and traditional leaders includes social-cultural potential in the community, community participation in the development of regional tourism, and the use of cultural symbols for the image of a city. Interviews with members of the Pampang village community include cultural performance practices to support regional tourism. All data collected is triangulated to obtain a reliable interpretive analysis.

\section{RESULTS AND DISCUSSION Picture of Samarinda Tourism}

Samarinda City is the capital of the province of East Kalimantan, Indonesia, and the largest city in the entire island of Kalimantan. Samarinda strived to become a city that has the branding TEPIAN (Shady, Neat, Safe, and Comfortable).

Samarinda's tourism is not natural tourism that has been born as beautiful as in some areas where tourism already integrated with nature. However, in Samarinda, the tour is more carried out by entrepreneurs and artificial tourism.

Artificial, in a sense, constructs the context of its destination. For example, tourist areas, such as Udin Area that builds the private sector. Mahakam Lantern Garden, indeed, the city government built, only managed in the private sector. The village of the rhombus is a pure citizen that residents also form tourist awareness groups.

These tour awareness groups have in the last two years, there were 4 or 5 
Tuti Widiastuti, dkk. Samarinda City Branding through Tourism Communication..

progresses in general, and the tour was from private. Furthermore, this built and the form of the Pokdarwis (kelompok sadar wisata or tourism awareness groups) based on the community, examples of Ketupat Village and Pampang Village as well. Then also, the Tanah Merah waterfall, which had been a long time ago, wanted to be revitalized. It is just that the problem here is now in terms of financing because it cannot help real money for its development destinations.

Entering the Provincial Government or the Central Government because the development of the destination is now aware that tourism is ranked 3rd in the city of Samarinda is the largest producer of Regional Original Revenue in Samarinda City. This confirmed by the statement from the Head of Regional Infrastructure, BAPPEDA Samarinda:

"Because the city of Samaridnda is a transit city, and the capital of the Province of East Kalimantan, it has principles as a City of Services, Industry and Trade. Based on the occupancy rate of passengers riding at the APT Pranoto airport it could be more than 3,000 people. It can even be said that people from East Kutai, Bontang, Sangata, Tenggarong, Kubar, if you do not need to fly to Balikpapan. Unless you want something there. If they chase time, they all ride in Samarinda. With the presence of Pranoto APT Airport, one of the routes open for tourism."

One of the local governments builds a tourism pier. Then look for investors who want to make tourist ships. So now Samarinda has five tour ships, even the six new ones want to launch again, there is another track to Hulu Mahakam. So from there can see that every weekend people want to get on board with extraordinary enthusiasm. Then it will sell this Mahakam River. Within passing through the Mahakam River every day, that many people are pulling the coal.
The following is the result of an interview with the Head of Self Assessment in the Field of Increasing Revenue in East Kalimantan: "Then we will sell the Mahakam River by thinking about how to sell the tourism sector. Every day through the Mahakam River there are many people who pull coal so they need to look for patterns to become power Even the riverside areas are arranged to be more interesting There are several places that are used to be a relaxed, relaxed area, to enjoy the river, and one more, for later developments on the Mahakam River in November, and later the Mahakam Festival will be held. every year, that's every year, even now he's 18 years, since 2000."

The pattern becomes an attraction; it is setting up these edge areas to make them more attractive. There are even some places that used to be a relaxed, relaxed area, to enjoy the river and one more thing, for later developments on the Mahakam River in November, and later the Mahakam Festival will be held every year.

\section{Samarinda City Branding}

Samarinda is throughout Indonesia and even abroad. For instance, Mahakam Travel Mart which was held on March 26-28, 2019, were attended by buyers and sellers who came from within and outside the country. The ones from abroad are from Thailand, Malaysia, Singapore. Then if from within the country, many from Java, Sumatra, Sulawesi. There are 200 buyers and 200 sellers, 400 companies. Even the one from Thailand opens the email directly. They believe it is because it is the first time selling. Why make Mahakam Travel Mart, because access to sell our tourism was able and feasible sold to the public.

The obstacles turn the palm in the tourism sector and have to slow down. However, it accompanied by a 


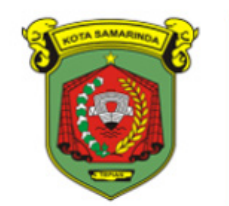

\section{SARINDA}

FIGURE 1. Logo Samarinda City
Branding

commitment, especially the policies of our leaders. The Mayor, in this case, is very intense once supporting the development of tourism is not easy. First, the access of amenities is now that is a supporting factor. Assibilates is now this is what needed to fix. If all access, all the tourist facilities in the area there, most importantly again, the area is clean, and that will make people want to come again. The FIGURE 1 is the logo of Samarinda City Branding.

The shield of Samarinda city depicts the people who defending themselves from challenges, threats, obstacles, and interference from anywhere The Mahakam bridge symbol strengthens the unity and unity of the nation. The combination of the letters A, M, and A is a connection of the word Samarinda.

Smart City is a City Government program through the Samarinda Office of Communication and Information. Meanwhile, Samarinda Tourism Office did not indirectly participate in this program. Considering the number of visits in Samarinda to stay or transit, a strategy is needed to increase the attractiveness of the city for investors. This can be done through smart city strategies (Martinez, Ugarte, \& Lorenzo, 2017), such as by re-empowering tourism in Samarinda's trade center in Citra Niaga. This business activity center was once the center to meet business people in the golden era, such as being a hangout center, souvenir center, and hawker center.

The following is quotation from an interview with the Head of Regional Infrastructure, BAPPEDA Samarinda: "Because of the number of visits,
Samarinda dwellings enter the tourism area. An example of a smart city from tourism is in Citra Niaga, where people meet in the era of its golden age. That's what we want to repeat again. So there is a hangout center, a souvenir center. we might come in as promoting out of Samarinda for that there is a location devoted to hanging out, souvenir center, hawker center, and so on. Well, one of the areas is Citra Niaga, it is a prestigious project."

For tourism, the Samarinda Government is planning to provide destination management training in a digital direction. So, for example, the management does not need to pay in cash, but it must be in the form of an e-card. They are collaborating with the banks, first design the city. Now the era must be like that, and the marketing era must be like a modern display. For example, destination governance, in terms of cover cash for the destination area, no longer needs to have to buy a ticket, maybe only with a bar-code or transfer banking that can connect with several destinations.

\section{The Building City Branding through Symbolic Interactionism}

The government's contribution to making Pampang Village an aspect of this tourism, the government is focusing on regulating it. The Dayak in Pampang Village is one of its hopes, excellent destinations (FIGURE 2). Therefore from now on, some priority programs for infrastructure improvement have started to be pushed to Pampang Village. With this incident, it can ensure that the population or groups that are in the village do the communication process and then interpret the events or steps and policies carried out by the government, and later they will share these interpretations with fellow internal residents, then they can build reality in reality. Social through communication so they can know, 
Tuti Widiastuti, dkk. Samarinda City Branding through Tourism Communication..

Pampang Village now bears the name of Culture Village.

The Dayak people apply their respect and belief through an art form that is sculpture. They carved walls, pillars, and even the wooden foundations of Lamin's house. Each of these ornaments has a particular meaning and function, both in terms of beliefs and philosophies. People use it in their work and especially in traditional rituals. Through art in particular making ornaments, they can express their identity, what they believe in, and their views of the natural surroundings, about their lives.

As in the Kayan people (Kenyah) love to decorate fields with a favorite motif of imaginary animals, such as a dragon combined with a dog animal, which decorated with arches which are then widely used to decorate doors and lawe (small items hanging in the form of thin boards cut in these motifs).

The form of carvings or ornaments made by each individual on "lamin" is one of the shared thoughts of the residents of Pampang Village. Forms of social interaction between them also consider each other's sides of each other. Because there seems to be a slight difference in belief forms ornaments or carvings in each ethnicity entering into one of the characteristics of an interactional perspective, which is symbolic interactionism itself.

In the Dayak traditional house called Lamin there are a variety of unique

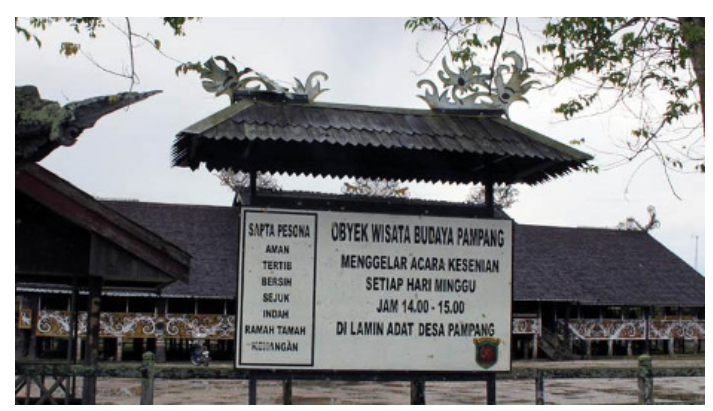

FIGURE 2. Tourism Culture in Pampang Village carvings, each of which has a distinctive meaning. Dayaks make carvings and ornaments on the interior and exterior of the building by carving walls, pillars and even the wooden foundations of the lamin houses. The ornaments in the interior of Lamin's house are incomparable, seen in terms of philosophical and belief the Dayak community towards the ancestors. Dayak Society applying their respect and trust through an art form that is sculpture and carving. The Dayak tribal dance performed at a traditional house that is called Lamin Adat Pamung Tawai.

As noted by Douglas (1970) meanings usually originate from interaction, and there is no other way to construct or shape that meaning, other than indeed by building relationships with other individuals through interaction (Ardianto, 2007, p. 136). This kind of interaction was also carried outby residents or communities who settled in Pampang Village. As in the current digitalization era, the Dayak people there also utilize cyberspace to communicate not only their internal but also communicating with the outside world (Sobur, 2007).

The concept of the situation definition is the implication of the concept of symbolic interaction about social interaction proposed by William Isaac Thomas (1968). The concept of this situation also applies, where "Lamin" is one of the traditional houses of Pampang Village which is the functional shift from what was once a shared residence, to a performance venue and a change in the function of space. Previously, "pagen" (terrace) was used as a meeting place for parents from the Dayak community to formulate decisions, turn into tourism objects. Pagen has now become a performance space and a place for spectators to sit and watch art performances on stage. So it can be said that there have been symptoms of cultural used which can be seen from the 
lamin and art activities in it as a tourist attraction.

These changes found mainly related to factors of migration and modernization. Based on the symbolic definition of interactionism, this situation shows where the Pambang people see themselves as part of cultural preservation through art performances. A sign of their reaction to external stimuli, such as migration and modernization factors brought about by tourists. Besides, the villagers in Pampang also agreed that traditional houses also called "lamin," are used as an art activity as a tourist attraction. There is influence from outside, then the behavior of the villagers is preceded by a particular stage of consideration and is not directly affected. In other words, stimulation from the outside is not directly done by the inhabitants. There is a selection or process of interpreting the situation, which in the end, the group will give eating of the stimuli that they receive.

It is not surprising if Pampang Village has become a cultural tourism, which since 1991 has become a public spotlight on the culture of the Dayak traditional dance. In this village, tourists can enjoy traditional dances typical of the Dayak tribe at the traditional house of Lamin Adat Pamung Tawai. A magnificent traditional house full of beautiful Dayak carvings. It is quite reasonable if the Samarinda Dayak Pampang Village has been named as one of the leading assets of local tourism because its presence encourage both local and foreign tourists.

The research findings of Pampang Village branding as a cultural tourism in Samarinda City is feasible for branding which can increase the value of the regional economy. That branding can describe a village that has tourism potential. The potentials of Pampang can be explored and can improve the economic flow in Samarinda City. Branding is carried out by the Village
Pampang as cultural tourism is one of the tourist attraction efforts carried out by the village government and the village of Pampang.

City branding itself is closely related to city planning which is used as a strategy to create a good positioning in marketing targets. To get recognition as the best city in certain aspects that depends on how the government makes city branding as a competitive force. The mission of Samarinda city, which is towards a smart city, the concept of city branding needs to be carefully thought out and optimally managed so that Samarinda will be widely known both nationally and globally.

\section{CONCLUSION}

The context of interaction of symbolism as a method in this study explains how the culture of the Pampang Village and Dayak tribe within it as a text or reality is laden with symbols. Referring to the method of symbolic interactionism, that the people of this part of Pampang Village, the Dayak tribe has various forms of culture and tradition. Behind the creation of culture and tradition, contained a lot of life values or cultural values that are now a genetic heritage of the Village Pampang itself. Before the creation of culture and tradition in Pampang, people passed through many aspects of the three thought themes of Mead. They start introducing symbolic through interaction and communication; then, they reach an agreement ]realized in the form of culture and tradition, which has now been preserved and introduced to the outside public.

The Dayak tribe in the village of Pampang have opened themselves through searching, identification, and deepening understanding of the meaning of the symbols contained behind their culture and traditions. The Dayak tribe is very careful in the use of ancestral 
Tuti Widiastuti, dkk. Samarinda City Branding through Tourism Communication..

symbols as part of the creation of selfidentity through concepts: mind, self, and society. The community has applied these three concepts in attitudes and behavior and culture which is understood to have a function in advancing the Dayak tribe in Pampang Village.

People in Pampang Village introduce their culture to the visitors for a better life because, at that time, there was a crisis. The tradition of tattooing and elongating ears by the Dayaks shows aspects of self-concept. Tattoo symbols or lengthen the ears have meaning and as a means of communication to the public outside. The tradition of tattoos gives information to fellow people inside or outside the community, what is the social status of the individual, and extends one's ear, which is a symbol to shape the community's self-concept in the village of Pampang itself, especially for women.

It is time for us to realize that the culture and tradition that Pampang Village or Dayak Tribe has is a valuable treasure from their ancestors or previous ancestors left to current generations. As a city branding strategy, related parties can maintain local traditions and culture as well as possible and objectively use ancestral cultural values for the development of a city.

\section{REFERENCES}

Ardianto, E. (2007). Komunikas Massa Suatu Pengantar. Bandung: Simbosa Rekatama Media.

Burhan, B. (2015). Komunikasi Pariwisata. Jakarta: Prenada Group.

Dila, S. (2008). Simbolisasi Etnik Muna di Bandung: Studi Identitas Etnik Orang Muna . Mediator, 9(2), 317326.

Fitraza, V. (2008). Teori Interaksi Simbolis. Bandung: PT Rineka Cipta .

Kavaratzis, M. (2004a). Cities and Their Brands: Lessons from Corporate Branding. Place Branding and Public Diplomacy, 5(1), 26-37.
Kavaratzis, M. (2004b). From City Marketing to City Branding: Towards a Theoretical Framework for Developing City Brands. Place Branding, 1(1), 58-73.

Keskin, H., Akgun, A. E., Zehir, C., \& Ayar, H. (2016). Tales and Cities: City Branding through Storytelling. Journal of Global Strategic Management, 10(1), 31-41.

Kotler, P. (2003). Manajemen Pemasaran. Jakarta: Gramedia.

Martinez, M. S., Ugarte, T. B., \& Lorenzo, F. C. (2017). The Smart City Apps as the Core of Place Branding Strategy: A Competitive Analysis of Innovation Cases. Zer Journal, 22(42), 119-135.

Moilanen, T., \& Rainisto. (2009). How to Brand Nations, Cities and Destinantions, a Planning Book for Place Branding. USA: Palgrave Macmillan.

Moleong, L. J. (2000). Metode Penelitian Kualitatif. Bandung: Remaja Rosdakarya.

Nallari, R., Griffith, B., \& Yusuf, S. (2012). Geography of Growth Spatial Economy and Competitiveness. Washington: World Bank.

Nugraha, A. R., Yustikasari, \& Koswara, A. (2017). Branding Kota Bandung di Era Smart City. Jurnal Ilmu Komunikasi, 8(1), 1-16.

Oktaviani, F. (2018). Strategi Branding Public Relations "Jendela Alam" dalam Mengembangkan Produk Agrowisata. Mediator, 11(2), 203213.

Pramiyanti, A. (2013). Strategi Word of Mouth Communication dalam City Branding Kota Bandung. Bandung: Telkom University.

Sobur, A. (2007). Karya Seni Sebagai Media. Mediator, 8(2), 211-220.

Sugiarsono. (2009). City Branding Bukan Sekedar Membuat Logo dan Slogan. Jakarta: SWA.

Sugiyono. (2013). Metode Penelitian Kuantitatif, Kualitatif, dan Kombinasi (Mixed Methods). Bandung: CV Alfabeta.

West, R., \& Turner, L. H. (2008). Introduction Communication Theory: Analysis 
MediaTor, Vol 13 (1), Juni 2020, 68-78

and Application. (M. N. Maer,

Trans.) Jakarta: Salemba Humanika.

Yananda, M. R., \& Salamah, U. (2014).
Branding Tempat: Membangun Kota, Kabupaten, dan Provinsi Berbasis Identitas. Jakarta: Makna Informasi. 